\title{
Company Performance: Are Environmental, Social, and Governance Factors Important?
}

\author{
Ekaterina Koroleva ${ }^{1 *}$, Michel Baggieri² ${ }^{2}$, Stella Nalwanga ${ }^{3}$ \\ ${ }^{1}$ Graduate School of Industrial Economics, Peter the Great St. Petersburg Polytechnic University, St. \\ Petersburg, Polytechnicheskaya, 29, 195251, Russia \\ ${ }^{2}$ Department of Management, Faculty of Economics, Sapienza University of Rome, Roma, Piazzale Aldo Moro \\ 5, 00161, Italy \\ ${ }^{3}$ Centre for Governance, Risk \& Accountability, University of Greenwich, London, Old Royal Naval College, \\ Park Row, Greenwich, SE10 9LS, United Kingdom
}

\begin{abstract}
Building on the resource-based view of entrepreneurship, we examine the association between environmental, social, and governance (ESG) factors and company performance, measured by return on assets, return on equity, and return on invested capital. We use regression models on a dataset of 60 observations of Russian companies including RAEX agency ESG ratings from 2018 to 2019. The results show that, in line with expectations, companies that comply with ESG principles demonstrate significantly better financial performance than other companies. This result holds true irrespective of the performance indicator used. Moreover, the governance factor is strongly related to company performance, providing implications for companies' policymakers in terms of the utility of adopting ESG information. The study provides insights into the resource-based view of entrepreneurship, demonstrating that ESG factors, and mainly the governance factor, create a competitive advantage for companies and allow superior performance.
\end{abstract}

Keywords: Environment; Governance; Performance; Social; Sustainability

\section{Introduction}

Since the last financial crisis, environmental, social, and governance (ESG) factors have received growing attention from multinational companies (Sahut and Pasquini-Descomps, 2015; Velte, 2016). According to an Ernst and Young (EY) survey, investors around the world are increasingly using ESG principles when choosing companies to invest in. Since 2014, the value of "responsible" investment capital has grown by a third every two years (Trends Report, 2018). As a result, many companies are striving to consider ESG principles as part of their development strategy. With the theme of responsible investing expected to continue to play a considerable role in company development, it is important to understand the influence of ESG factors on corporate performance. In addition, a recent literature review by Gerard (2019) highlights the need to investigate the drivers of company success. We address this gap from the perspective of ESG factors.

Nowadays, there are many different definitions of and terms for responsible investing and ESG principles. In the framework of this research, we use a definition of ESG principles based on the European Commission's vision and on the United Nations Principles (Galvin, 
2019). Analysis of the elements that make up the concept ESG must inevitably be sought in the individual components of the acronym. Environmentalism stands for the principles of green finance, understood as the process of decision making in the investment phase. Social considerations may refer to issues of inequality, inclusiveness, labor relations, investment in human capital, and communities. The governance of public and private institutions, including management structures, employee relations, and executive remuneration, plays a fundamental role in ensuring the inclusion of social and environmental considerations in the decision-making process. The integration of the three components constitutes a set of sustainable development principles both in economic and financial terms. The interpretation of ESG used in the framework of this research was selected for two main reasons. First, the subject of study is Russian companies. Russian legislation on the subject has been developed according to American and European standards and principles. The second is the fact that the ESG ratings of Russian companies were developed by the European rating agency, which uses current European and American sustainability principles.

The theoretical background of the research is the resource-based view of entrepreneurship (Barney, 1991; Newbert, 2007). It assumes that the key drivers of company performance are resources that are difficult to imitate. Resources make it possible for a company to create a competitive advantage and achieve superior performance. We suppose that ESG factors can be considered difficult-to-imitate resources. Scientific literature has found different and heterogeneous results about the relationship between ESG scores and performance indicators. For example, several authors (Hart, 1995; Christmann, 2000; Clarkson et al., 2011) suggest that companies with more significant financial resources and superior management capabilities do not benefit from having a proactive environmental strategy. According to some researchers, the social factor in the business model of companies can also set back operational and financial performance (Yunus et al., 2010; Siew, 2012).

The goal of this paper is to analyze the association between ESG factors and company performance. Regression models are used on a dataset of 60 observations of 30 Russian companies from 2018 through 2019. The results show that company performance depends on the company's position in ESG ratings. Performance indicators are higher for companies with policies that support ESG principles. Moreover, governance is a crucial factor and has the most influence of any principle on company performance in Russia.

This paper contributes to the literature on the resource-based view of entrepreneurship (Barney, 1991; Leung et al., 2014; Sharma et al., 2019) by revealing ESG factors as difficult-to-imitate resources. It also complements the literature on ESG in Russia (Atnashev and Vashakmadze, 2014; Glazova, 2018) by being the first to evaluate the association between ESG factors and company performance. To the knowledge of the authors, no previous paper has investigated the influence of ESG factors on company performance in Russia. This study should help company managers to shift their focus to non-financial indicators and to adopt new business models to achieve competitive advantages.

The paper is structured as follows. Section 2 provides an overview of the theoretical background of the research. Data and methods are discussed in section 3. Results and discussion are presented in section 4 . Finally, section 5 provides the conclusion.

\section{Literature Review}

The resource-based view of entrepreneurship emerged in the field of strategic management in the late 20th century (Prahalad and Hamel, 1990; Barney, 1991). It 
supposes that company resources are the main determinants of performance. Only rare and difficult-to-imitate resources allow a company to achieve a competitive advantage. The resource-based view of entrepreneurship has been widely tested and broadly supported in numerous studies (Newbert, 2007). In the framework of this research, we assume that ESG factors are complex and difficult-to-imitate resources and try to fill the gap in existing research by analyzing the association between ESG factors and company performance.

ESG scores provide transparency of information that is useful to both investors and managers of companies (Kocmanová and Dočekalová, 2012). Several case studies prove there is a positive correlation between the implementation of ESG practices and company performance. Pasquini-Descomps and Sahut (2014) revealed the positive influence of ESG factors on company performance in their study considering 11 Swiss banks. Ortas et al. (2015) and Brogi and Lagasio (2019) obtained similar results. The authors attributed this relationship to investment practices which favor sustainable investment projects that guarantee workers' rights and improvements in the management and corporate governance of organizations. Based on the studies mentioned above, the researchers developed the following hypotheses:

H1: ESG is positively associated with company performance.

However, many antitheses could be raised contesting this general idea and the positive influence of ESG on financial and operational returns (Atan et al., 2018). Empirical research by Horváthová (2010) shows that the probability of finding a negative impact of ESG factors on performance indexes increases with the complication of the linear coefficients used in the model. Siew (2012) showed that ESG scores are also negatively associated with the performance of Australian companies.

Taking into account the separate analysis of ESG factors, we reveal that, in this case, the results are more heterogeneous and ambiguous. In the course of the study, it was found that the real positive impacts of ecological factors on financial performance were measured across a range of financial ratios (Siew et al., 2013). The study conducted by Russo and Fouts (1997) on a sample of 477 companies demonstrated a positive relationship between the ecological factor and return on assets. The meta-analysis conducted by Albertini (2013), who analyzed 52 previous studies, also confirms the previous results. Therefore, we propose the following hypothesis:

H2: Environmental factors are positively associated with company performance.

As pointed out above, environmentally-friendly investment practices do not have the same positive effect on performance and risk indicators for all companies (Freedman and Jaggi, 1982).

Edmans (2011) proves that the effects of social actions improve share returns by nearly $2.3 \%$ annually. Several researchers have focused their attention on the role of corporate philanthropic donations. A study by Brammer and Millington (2008) shows that companies that focus on charity achieve higher financial returns than others. These results lead to the following hypotheses:

H3: Social factors are positively associated with company performance.

Many studies aimed at analyzing the effect of good governance policies (transparency in reports, shareholder involvement, responsible behavior, ownership structure, independent managers) have shown greater homogeneity in results than those analyzing the previous factors. Most of the authors find as a common and undeniable result that better quality governance and higher transparency of managerial actions improve financial performance (Gompers et al., 2003; Giroud and Mueller, 2010). The findings of the empirical study carried out by Cremers and Nair (2005) affirm that well governed 
companies achieve an extra annual redemption of 10-15\%. Generally, we can formulate the following:

H4: Governance is positively associated with company performance.

\section{Data and Methods}

We collected data on 30 Russian organizations rated on ESG factors by RAEX, an independent rating agency. According to the methodology adopted by RAEX (2017), in their social reports the 30 companies for which the scoring was carried out pay particular attention to the themes of corporate social responsibility, investments in sustainability, environmental respect and improvement of workforce management. The ratings were issued twice, in 2019 and 2018. In order to be included in the ratings and our dataset, the companies had to be registered in Russia and listed on the Russian stock exchange.

Data on financial and ESG factors were combined with information hand collected from official websites of the companies and the Rusprofile database. Due to difficulties encountered in the conversion of different currencies, data from financial reports prepared by Russian Accounting Principles was given preference. The final dataset used for estimations contains data on 60 observations of 30 companies. The analyzed companies come from a variety of different sectors (Table 1 ).

Table 1 The distribution of companies by sector

\begin{tabular}{lcl}
\hline \multicolumn{1}{c}{ Sector } & Number of companies & \multicolumn{1}{c}{ Company names } \\
\hline Mining industry & 9 & $\begin{array}{l}\text { MMK, Alrosa, NMLK group, UC Rusal, Evraz, } \\
\text { Severstal, Metalloinvest, Mechel, UMMC, Norilsk } \\
\text { Nickel }\end{array}$ \\
\hline $\begin{array}{l}\text { Petroleum industry } \\
\text { Electric power } \\
\text { industry }\end{array}$ & 8 & $\begin{array}{l}\text { Lukoil, Tatneft, Gazprom, Rosneft, Novatek, } \\
\text { Sibur holding, Surgutneftegaz, Trasneft }\end{array}$ \\
\hline Transport industry & 2 & $\begin{array}{l}\text { Rosseti, Inter RAO, Rushidro, Sakhalin energy, } \\
\text { Siberian Coal Energy Company, Tplus }\end{array}$ \\
\hline Engineering industry & 2 & $\begin{array}{l}\text { Russian Railways, Aeroflot } \\
\text { Nuclear industry }\end{array}$ \\
\hline $\begin{array}{l}\text { Mineral fertilizer } \\
\text { production }\end{array}$ & 1 & $\begin{array}{l}\text { United Shipbuilding Corporation, United } \\
\text { Aircraft Corporation }\end{array}$ \\
\hline
\end{tabular}

The sectors best represented by the analyzed companies represent the greatest strengths of the country's economic development. This sample of companies subject to ESG analysis is concentrated in the metallurgical, energy, oil, and gas extraction sectors. These sectors represent the core of Russia's GDP (Zlobina et al., 2019).

Performance variables are used as dependent variables in regression models. Many different indexes are used to measure performance (Gozali et al., 2020). In one type of research the authors use absolute performance indicators such as gross profit, revenue, and net profit (Santos and Brito, 2009; Fried and Tauer, 2015). Unfortunately, in this case it is not suitable to use such indicators because the companies in the analyzed dataset are of varying sizes and come from different sectors. More often, authors use traditional indicators such as return on assets (ROA), return on equity (ROE), and return on invested capital (ROIC) (Mayer-Haug et al., 2013). These indicators allow for both evaluating performance of a company and comparing companies of various sizes. The indicators are 
also suitable for this research because none of the analyzed companies is a high-tech company (Brooks and Oikonomou, 2018).

Based on the identified hypotheses, we analyze the company's overall position in the RAEX ratings (ESG) and position for each indicator (E, $S \& G$ ) as explanatory variables. The ESG scoring for the 30 companies was carried out by RAEX using a rating scale. Companies following ESG principles got higher scores and positions in the rating. This means that, in the framework of this research, a negative association between position in the RAEX ratings and company performance will prove the suggested hypothesis. According to the ESG rankings published on RAEX's official website in 2018-2019, the best performing companies were Lukoil, MMK, and Tatneft. The worst ESG total scores were received by United Aircraft Corporation and UMMC.

In order to integrate a proportional measure referring to company size in the statistical model, we collected data referring to two controllable variables: number of employees (Em) and natural logarithm of total assets (lnta).

The descriptive statistics of dependent and controllable variables are presented in Table 2.

Table 2 Descriptive statistics of dependent variables

\begin{tabular}{lllcccc}
\hline Variable & Description & Obs. & Mean & Std. Dev. & Min & Max \\
\hline ROA & return on assets & 60 & 0.29 & 0.63 & 0.01 & 4.53 \\
\hline ROE & return on equity & 60 & 0.37 & 0.53 & -0.59 & 3.10 \\
\hline ROIC & $\begin{array}{l}\text { return on } \\
\text { invested capital }\end{array}$ & 60 & 0.23 & 0.20 & 0.01 & 0.76 \\
\hline Inta & $\begin{array}{l}\text { natural log of } \\
\text { total assets }\end{array}$ & 60 & 20.01 & 1.59 & 16.31 & 23.48 \\
\hline Em & $\begin{array}{l}\text { number of } \\
\text { employees }\end{array}$ & 60 & 113104.50 & 155479.70 & 2277.00 & 755000.00 \\
\hline
\end{tabular}

As can be seen from the table, the three performance indicators are rather heterogeneous. There is no particular reason for these deviations except for the heterogeneity of the analyzed sectors, the global context of the industrial economy, and intrinsically random features. The control variables were chosen to be integrated in the statistical model to eliminate the scope of company activities. The natural log of total assets has the lowest variability, which is due to the specifics of the variable. The high variability of the Em variable is also explained by variations in company size.

Due to a limited sample period, we estimate regression models where identified indicators are calculated within 2017-2018.

We test $\mathrm{H} 1 \mathrm{using}$ the following model:

$$
\text { Perf }_{\mathrm{i}}=\mathrm{f}(\mathrm{ESG} ; \operatorname{lnta} \text { EM) }
$$

$\mathrm{H} 2$ to $\mathrm{H} 4$ are tested using the following model:

$$
\operatorname{Perf}_{\mathrm{i}}=\mathrm{f}(\mathrm{E} ; \mathrm{S} ; \mathrm{G} ; \operatorname{lnta} ; \mathrm{EM})
$$

Perfi refers to one of the three performance indexes (ROA, ROE, ROIC).

We use pooled OLS regression analysis, modelling the performance of the firm as a function of the following explanatory variables: ESG rating, total assets and number of employees. The regression estimations control for heteroscedasticity. In the tables presented, it is specified that robust standard errors are reported. 


\section{Results and Discussion}

We have carried out the correlation matrix of the independent variables in order to avoid multicollinearity of factors (Table 3). This provides a statistical adjustment to the correlations among the remaining variables using multiple regression.

Table 3 Correlation matrix

\begin{tabular}{c|cccc}
\hline & Inta & ESG & E & S \\
\hline Inta & 1 & & & \\
ESG & -0.45 & 1 & & \\
E & -0.29 & 0.72 & 1 & 1 \\
S & -0.37 & 0.84 & 0.45 & 0.40 \\
G & -0.40 & 0.59 & 0.19 & \\
\hline
\end{tabular}

As can be seen from the table, the ESG rating is correlated with the environmental and social rating. Since these factors are used in models to test different hypotheses, these factors were left for further investigation.

The results of testing the ESG rating against company performance are presented in Table 4.

Table 4 H1: Regression results

\begin{tabular}{ccccccc}
\hline Dependent variable & ROA & & ROE & & ROIC & \\
\hline Constant & 4.20 & $* * *$ & 0.70 & $* * *$ & 0.93 & $* *$ \\
& $(0.79)$ & & $(0.17)$ & & $(0.37)$ & \\
ESG & -0.02 & $* *$ & -0.01 & $*$ & -0.01 & $*$ \\
& $(0.01)$ & & $(0.01)$ & & $(0.00)$ & \\
Inta & -0.20 & $* * *$ & & & -0.03 & \\
& $(0.04)$ & & & & $(0.02)$ & \\
Em & 0.00 & $* * *$ & -0.00 & $* *$ & -0.00 & $* *$ \\
& $(0.00)$ & & $(0.00)$ & & $(0.00)$ & \\
No. of obs. & 60 & & 60 & & 60 & \\
Adj. R2 & 0.590 & & 0.055 & & 0.079 & \\
F stat. & 29.26 & $* * *$ & 2.722 & $* * *$ & 2.692 & $* * *$ \\
\hline
\end{tabular}

A negative correlation between the dependent and explanatory variables means the ESG factors have a positive effect of on the financial performance indicators. In line with expectations (H1), companies that follow ESG principles have higher performance indexes. This result holds true irrespective of the performance indicator used. However, the results show a discreet influence of the ESG factor on ROA and less significant effects on ROE and ROIC. Companies that are oriented to ESG principles have 2\% higher ROA and 1\% higher ROE and ROIC. This supports H1.

In terms of control variables, we observe a rather significant association between number of employees and the performance indexes. The natural log of total assets is significant only in the case of ROA. Table 5 presents the results of the influence of the separate environmental, social, and governance ratings on the performance indexes.

In Table 5, for each performance index, we present the initial (2.1) and final (2.2) versions of the model. In the context of ROA, governance has a strongly negative association with the identified performance index. This means that companies that take governance aspects into account have $2 \%$ higher ROA overall. Environmental and social factors appear statistically insignificant in this case. 
Table 5 H2, H3, H4: Regression results

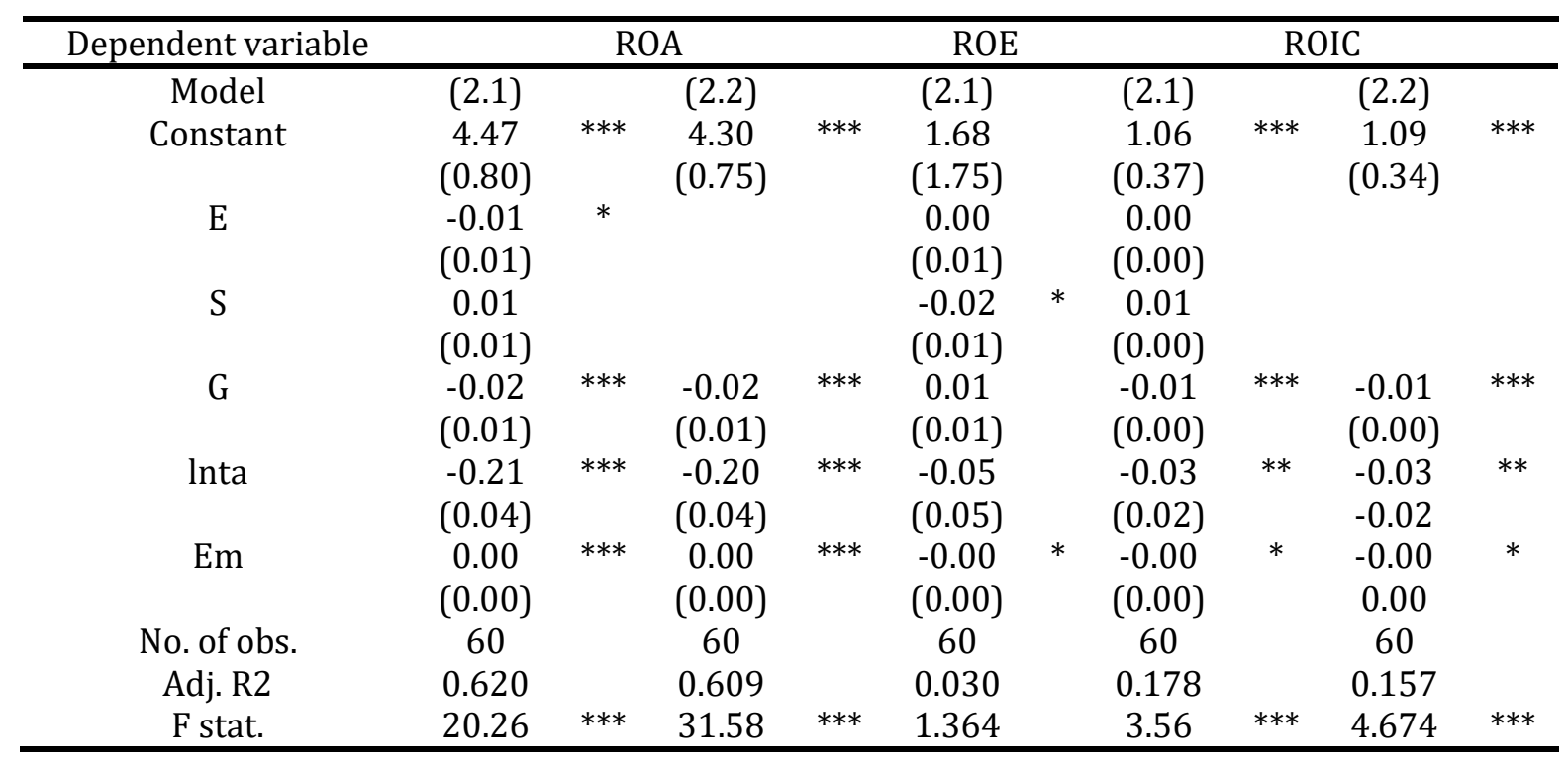

We get similar results for another performance index: ROIC. Only the governance rating influences this performance indicator. Companies with policies oriented to governance aspects have $1 \%$ higher ROIC. In the case of ROE, we obtained insufficient dependence and unsatisfactory results that is why we do not present the final version of the model (2.2). In terms of control variables, we observe a rather significant association between them and the performance indexes.

As a result, the strongest support for $\mathrm{H} 4$ is found for the positive association between the governance rating and the performance indicators ROA and ROIC. Companies oriented toward governance factors have a competitive advantage that is reflected in superior financial performance. Environmental factors appear statistically significant only in the initial model using ROA as a dependent variable. In this model, companies oriented toward environmental factors have higher ROA. Considering that the variable became statistically insignificant in the final version of the model, $\mathrm{H} 2$ is not supported. In terms of social factors, we also fail to observe the superiority of socially responsible companies' financial performance (H3).

Relying on the resource-based view of entrepreneurship, we reveal that ESG factors,are rare and difficult-to-imitate resources that allow companies in Russia to achieve superior performance and obtain a competitive advantage.

\section{Conclusions}

Our paper provides additional evidence related to the resource-based view of entrepreneurship. We show that, in line with expectations (H1), Russian companies oriented to ESG principles tend to exhibit superior performance than others. This result confirms previous research (Pasquini-Descomps and Sahut, 2014; Ortas et al., 2015; Hassan et al., 2018; Brogi and Lagasio, 2019). It also supports the view that ESG policies are an essential factor in business development that give the company great opportunities to improve efficiency. ESG initiatives help companies at all stages of the value chain, from reducing costs to securing a competitive advantage. ESG encourages companies interested in investments and listed on the stock exchange to consider sustainability and thus contributes to a more robust green securities market. As our 
dataset was restricted to ESG ratings from two years only, this aspect deserves attention in future studies focusing on Russian companies as well as on other countries.

In the context of the separate analysis of ESG factors, we found strong support for H4: Russian companies with policies aimed at good governance have higher performance indicators. These results expand the findings of previous studies (Gompers et al., 2003; Cremers and Nair, 2005; Brammer and Millington, 2008; Ting et al., 2020; Zhang et al., 2020). Environmental and social ratings would seem to influence company performance. However, contrary to expectations, we failed to observe that companies with policies focused on social and environmental factors performed better than others (H2, H3). Interestingly, the ESG rating consists of three elements in equal parts but when they are analysed separately only one is statistically significant. In comparison with the other factors, governance encompasses the largest number of indicators: board of directors; ownership; business ethics; anti-competition practices; risk management; accounting; and taxation disclosure. In Russian practice, the identified indicators play a vital role in the conditions of economic and political instability.

The results obtained from the two regression models show that it is possible to implement sustainability policies even in the absence of a strong regulatory base, which is common in Russia. Today's regulatory base in Russia is substantially lacking in comparison with that in Europe. The analyzed companies currently provide a fair degree of voluntary disclosure and are leading the way toward improving reporting policies in Russia. Russia is one of the major BRICS countries and is already turning toward the new business models exemplified by these companies.

This empirical study was able to demonstrate that, at least for Russian companies from industrial sectors, policies focused on mainly good governance can improve profitability.

\section{Acknowledgements}

The research is funded by the Russian Science Foundation (project No. 20-78-10123).

\section{References}

Albertini, E., 2013. Does Environmental Management Improve Financial Performance? A Meta-Analytical Review. Organization \& Environment, Volume 26(4), pp. 431-457

Atan, R., Alam, M.M., Said, J., Zamri, M., 2018. The Impacts of Environmental, Social, and Governance Factors on Firm Performance. Management of Environmental Quality: An International Journal, Volume 29(2), pp. 182-194

Atnashev, T., Vashakmadze, T., 2014. From Socially Responsible Investment to Socially Responsible Business: Historical Analogies and Financial Models for Russia. Financial life, Volume (4), pp. 41-48

Barney, J., 1991. Firm Resources and Sustained Competitive Advantage. Journal of Management, Volume 17(1), pp. 99-120

Brammer, S., Millington, A., 2008. Does It Pay to Be Different? An Analysis of the Relationship Between Corporate Social and Financial Performance. Strategic Management Journal, Volume 29(12), pp. 1325-1343

Brogi, M., Lagasio, V., 2019. Environmental, Social, and Governance and Company Profitability: Are Financial Intermediaries Different? Corporate Social Responsibility and Environmental Management, Volume 26(3), pp. 576-587 
Brooks, C., Oikonomou, I., 2018. The Effects of Environmental, Social and Governance Disclosures and Performance on Firm Value: A Review of the Literature in Accounting and Finance. The British Accounting Review, Volume 50(1), pp. 1-15

Christmann, P., 2000. Effects of "Best Practices" of Environmental Management on Cost Advantage: The Role of Complementary Assets. The Academy of Management Journal, Volume 43(4), pp. 663-680

Clarkson, P.M., Li, Y., Richardson, G.D., Vasvari, F.P., 2011. Does it Really Pay to be Green? Determinants and Consequences of Proactive Environmental Strategies. Journal of Accounting and Public Policy, Volume 30(2), pp. 122-144

Cremers, K.M., Nair, V.B., 2005. Governance Mechanisms and Equity Prices. The Journal of Finance, Volume 60(6), pp. 2859-2894

Edmans, A., 2011. Does the Stock Market Fully Value Intangibles? Employee Satisfaction and Equity Prices. Journal of Financial Economics, Volume 101(3), pp. 621-640

Freedman, M., Jaggi, B., 1982. Pollution Disclosures, Pollution Performance and Economic Performance. Omega, Volume 10(2), pp. 167-176

Fried, H.O., Tauer, L.W., 2015. An Entrepreneur Performance Index. Journal of Productivity Analysis, Volume 44(1), pp. 69-77

Galvin, G., 2019. EU Commission Presents Roadmap to Make Europe Climate-Neutral by 2050. Ireland - European Commission. Available Online at https://ec.europa.eu/ireland/news/eu-commission-presents-roadmap-makeeurope-climate-neutral-2050_en, Accessed on December 12, 2020

Gerard, B., 2019. ESG and Socially Responsible Investment: A Critical Review. Beta, 2019, Volume 33(01), pp. 61-83

Giroud, X., Mueller, H.M., 2010. Does Corporate Governance Matter in Competitive Industries? Journal of Financial Economics, Volume 95(3), pp. 312-331

Glazova, S.C., 2018. The Impact of ESG Factors on the Sustainable Development of Companies and the Financial Performance of the Corporate Sector. Bulletin of the Rostov state University of Economics, Volume 4(64), pp. 81-86

Gompers, P., Ishii, J., Metrick, A., 2003. Corporate Governance and Equity Prices. The Quarterly Journal of Economics, Volume 118(1), pp. 107-156

Gozali, L., Masrom, M., Zagloel, T.Y.M., Haron, H.N., Garza-Reyes, J.A., Tjahjono, B., Irawan, A.P., Daywin, F.G., Syamas, A.F., Susanto, S. Harry, K.K.A., Marie I.A., 2020. Performance Factors for Successful Business Incubators in Indonesian Public Universities. International Journal of Technology, Volume 11(1), pp. 155-166

Hart, O., 1995. Corporate Governance: Some Theory and Implications. The Economic Journal, Volume 105(430), pp. 678-689

Hassan, M.G., Akanmu, M.D., Yusoff, R.Z., 2018. Technological Integration and Sustainable Performance in Manufacturing Firms. International Journal of Technology, Volume 9(8), pp. 1639-1650

Horváthová, E., 2010. Does Environmental Performance Affect Financial Performance? A Meta-Analysis. Ecological Economics, Volume 70(1), pp. 52-59

Kocmanová, A., Dočekalová, M., 2012. Construction of the Economic Indicators of Performance in Relation to Environmental, Social and Corporate Governance (ESG) Factors. Acta Universitatis Agriculturae et Silviculturae Mendelianae Brunensis, Volume 60(4), pp. $195-206$

Leung, W.S., Barwick-Barrett, M., Evans, K.P., 2014. Resource Efficiency and Firm Value. Available Online at https://www.osmosisim.com/wpcontent/uploads/2017/11/Resource-Efficiency-Firm-Value.pdf, Accessed on December 12, 2020 
Mayer-Haug, K., Read, S., Brinckmann, J., Dew, N., Grichnik, D., 2013. Entrepreneurial Talent and Venture Performance: A Meta-Analytic Investigation of SMEs. Research Policy, 42(6-7), pp. 1251-1273

Newbert, S.L., 2007. Empirical Research on the Resource-based View of the Firm: An Assessment and Suggestions for Future Research. Strategic Management Journal, Volume 28(2), pp. 121-146

Ortas, E., Álvarez, I., Jaussaud, J., Garayar, A., 2015. The Impact of Institutional and Social Context on Corporate Environmental, Social and Governance Performance of Companies Committed to Voluntary Corporate Social Responsibility Initiatives. Journal of Cleaner Production, Volume 108(Part A), pp. 673-684

Pasquini-Descomps, H., Sahut, J.-M., 2014. ESG Impact on Market Performance of Firms: International Evidence. Management International, Volume 19(2), pp. 40-63

Prahalad, C.K., Hamel, G., 1990. The Core Competence of the Corporation. Harvard Business Review, Volume 68(3), pp. 79-91

Russo, M.V., Fouts, P.A., 1997. A Resource-based Perspective on Corporate Environmental Performance and Profitability. The Academy of Management Journal, Volume 40(3), pp. 534-559

Sahut, J.-M., Pasquini-Descomps, H., 2015. ESG Impact on Market Performance of Firms: International Evidence. Management International/International Management/ Gestiòn Internacional, Volume 19(2), pp. 40-63

Santos, J.B., Brito, L.A.L., 2009. Toward a Measurement Model for Firm Performance. Encontro De Estudos Em Estratégia-Anpad (Strategy Studies Meeting - Anpad), Volume 4, pp. 1-16

Sharma, D., Bhattacharya, S., Thukral, S., 2019. Resource-based View on Corporate Sustainable Financial Reporting and Firm Performance: Evidences from Emerging Indian Economy. International Journal of Business Governance and Ethics, Volume 13(4), pp. 323-344

Siew, R., 2012. ESG Scores and Its Influence on Firm Performance: Australian Evidence. In: Australian School of Business School of Accounting, School of Accounting Seminar Series Semester Volume 2, University of New South Wales, Australia, pp. 1-30

Siew, R.Y.J., Balatbat, M.C.A., Carmichael, D.G., 2013. The Relationship between Sustainability Practices and Financial Performance of Construction Companies. Smart and Sustainable Built Environment, Volume 2(1), pp. 6-27

Ting, I.W.K., Azizan, N.A., Bhaskaran, R.K., Sukumaran, S.K., 2020. Corporate Social Performance and Firm Performance: Comparative Study among Developed and Emerging Market Firms. Sustainability, Volume 12(1), pp. 1-21

Trends Report, 2018 | GSIA. Available Online at http://www.gsi-alliance.org/trends-report2018/, Accessed on July 21, 2020

Velte, P., 2016. Women on Management Board and ESG Performance. Journal of Global Responsibility, Volume 7(1), pp. 98-109

Yunus, M., Moingeon, B., Lehmann-Ortega, L., 2010. Building Social Business Models: Lessons from the Grameen Experience. Long Range Planning, Volume 43(2-3), pp. 308325

Zhang, Q., Loh, L., Wu, W., 2020. How do Environmental, Social and Governance Initiatives Affect Innovative Performance for Corporate Sustainability? Sustainability, Volume 12(8), pp. 1-18

Zlobina, N., Kondrakov, O., Merkulova, E., Muratova, O., Vetakova, Y., 2019. Impact of Energy Economy Development on the Region's Population Life Quality. E3S Web of Conferences, Volume 110. EDP Sciences, p. 02106 